\title{
THE PUBLIC LAW DIMENSION OF PUBLIC AUTHORITY LIABILITY
}

\author{
Tom Cornford ${ }^{*}$
}

\begin{abstract}
In 2008, the Law Commission published a consultation paper on Administrative Redress. The paper was informed by the basic assumption that the problem of administrative liability in English law can only be understood by examining both its tortious and its public law dimensions and that a satisfactory solution would involve a form of liability that straddled the public/private divide. In this article I endorse the Law Commission's assumption. I advance a rationale for a form of liability that involves reparation for harms resulting from acts unlawful as a matter of public law and argue that the form of liability that the rationale supports would inevitably impinge upon the territory currently occupied by the law of tort. I then proceed to criticise the views of scholars who have recently argued that a satisfactory law of public authority liability can be arrived at by the use of the concepts of orthodox tort law alone.
\end{abstract}

\section{INTRODUCTION}

In 2008, the Law Commission published a consultation paper entitled Administrative Redress: Public Bodies and the Citizen. ${ }^{1}$ The paper considered, amongst other things, the issue of when a monetary remedy should be awarded to citizens who suffer harm as a result of unlawful administrative action (i.e. who are the victims of "public law wrongs" as I shall call them) and it canvassed the familiar failings in this respect of current law. It pointed out the absence of a remedy in a number of situations which appear to call for one. It mentioned, for example, the case of the taxi driver deprived of a license during the period of challenge to a wrongful decision to remove it, ${ }^{2}$ the farmer prevented from marketing his cattle by an erroneously

\footnotetext{
* Dr Tom Cornford, MA Cantab, LLM London, Barrister, Senior Lecturer Essex University School of Law.

1 Consultation Paper No.187, available on the Law Commission's website at $<$ http://lawcommission.justice.gov.uk/docs/cp187_Administrative_Redress_Consultat ion.pdf $>$ accessed 6 May 2013.

${ }^{2} R$ v Knowsley Borough Council ex parte Maguire [1992] COD 499.
} 
made movement restriction order, ${ }^{3}$ and the person who loses his job when he is mistakenly placed on a child abuse register. ${ }^{4}$ It also drew attention to the pervasive uncertainty and instability of the law of tort, and in particular the law of negligence, in so far as it relates to public authorities. The Commission's proposed solution was, in essence, a single form of liability that straddled the boundaries of public law and the law of tort. The proposal was welcomed by some ${ }^{5}$ and subject to a great deal of criticism from others ${ }^{6}$ but it was, in any case, strongly opposed by the government and consequently abandoned. At the same time, during roughly the period of gestation of the Law Commission's project, the courts became increasingly conservative. The prospects of success for a claimant seeking compensation from public authorities for misuse of their powers diminished. ${ }^{7}$ We are thus left with a situation in which the deficiencies identified by the Law Commission remain but in which there is little immediate prospect of the courts or the government doing anything about it.

The status quo - or aspects of it - has its defenders. Amongst recent writers, there are those who on the one hand, accept that there exists in the law as a whole deficiencies of the sort identified by the Law Commission but who, on the other, insist that the private law of tort must continue as before, unruffled by the problems that afflict public law. In this article I wish to consider the recently expressed views of two respected scholars who take this view, Donal Nolan and Roderick Bagshaw. In recent writing on the law of negligence, the first defends the position currently taken by the courts and suggests that any lacuna in the system for holding public authorities to account must remain the province of public law while the second suggests an incremental extension of the duty of care to cover one type of case in which citizens are harmed by unlawful administrative action while appearing to accept that the court's general position with regard to the liability of public authorities should remain the same.

The view I shall take here is that the Law Commission was right in its basic contention and the supporters of the status quo wrong: one cannot arrive at a defensible view as to how the law of tort should apply to public bodies

\footnotetext{
${ }^{3} R$ (Banks) v Secretary of State for Health [2004] EWHC 416 (Admin), [2004] NPC 43.

${ }^{4} R$ v Norfolk County Council Social Services Department ex parte M [1989] QB 619.

${ }^{5}$ See eg K Oliphant, Tort and Insurance Law Yearbook: European Tort Law 2008 (ESRETL 2008) 219.

${ }^{6}$ See Law Commission Analysis of Consultation Responses at $<$ http://lawcommission.justice.gov.uk/docs/lc322_Administrative_Redress_responses. pdf $>$ accessed 6 May 2013.

${ }^{7}$ The most obvious manifestation of this is the Gorringe case discussed further below.
} 
without attending to the public law as well as to the tortious dimensions of the problem and any attempt to do so will lead to unsatisfactory results. The focus of the commentators whose arguments I shall consider is on negligence and, as a consequence, most of my criticisms of those arguments will also concern negligence. But if the commentators are right to think that the correct approach to the negligence liability of public authorities can be determined without considering the position of public authorities in public law then it must, by the same token, be possible to disregard the position of public authorities in public law in determining the correct approach to their liability in tort law as a whole. The conclusions I draw will thus concern tort law generally and not just the law of negligence.

The plan of the article is as follows. In Part 2, I shall briefly set out what I consider to be the strongest argument for the creation of a form of liability specifically concerned with public law wrongs. It will be seen that the form of liability it supports would inevitably impinge upon the existing law of tort. In Part 3, I shall examine the arguments of Nolan and in Part 4 those of Bagshaw. The argument I make in Part 2 may be subject to myriad objections and in the course of this single article I cannot hope to rebut these or to convince sceptics that the form of liability it supports is the right one. Nor will pointing out the flaws in Nolan and Bagshaw's position show conclusively that my belief in the inescapable salience of the public law dimension is correct. But I will, I hope, have done enough to show that the case for a form of tort liability with an explicitly public law dimension cannot be dismissed without a detailed answer from those opposed to it.

\section{THE CASE FOR A UNITARY ADMINISTRATIVE LIABILITY}

The following argument presents, I suggest, the strongest reason for developing the law so as to provide reparation for public law wrongs. It also expresses the underlying normative impulse that has led many to view the present failure of the law to provide such reparation as unfair. ${ }^{8}$ I present the argument in numbered steps.

1.Although separate (but overlapping) bodies of law apply to public bodies and private persons, there are certain basic moral and legal principles that apply to both.

${ }^{8}$ Cf the argument made in T Cornford, Towards a Public Law of Tort (Ashgate 2008). 
2.One such principle is what might be called a principle of corrective justice, namely that those who are responsible for the wrongful losses of others have a duty to repair them.

3.It follows that where a citizen suffers loss as a result of a public law wrong committed by a public body with respect to that citizen, the public body is under a duty to repair the loss.

4.Step 3 is open to the obvious objection that public law wrongs are wrongs to society as a whole rather than to individuals and that it cannot therefore be right to award compensation to citizens who happen to suffer loss as a result of them. The answer is that, properly understood, the norms of public law perform a dual function. On the one hand, they ensure that public bodies act with fidelity to the public purposes for which their powers are granted. On the other hand, they ensure that public bodies act with fairness towards individuals and infringe their private interests no more than can be justified by reference to the lawful public aims that they seek to attain. Breach of those public law norms intended to protect individuals may result in loss to the individuals concerned and it is in these circumstances that the award of compensation is appropriate. On this basis, we may also say that public bodies owe duties to those affected by their actions to treat them in accordance with the norms of public law and that, correspondingly, those affected possess entitlements to be so treated.

The argument may be made clearer by a pair of examples. Imagine, firstly, that a public body has the power to award and to revoke licences that are necessary if a company is to market a drug. Suppose further that the body purports to revoke a company's licence on a particular ground when on a correct reading of the law it does not have the power to do so and that as a result the company suffers loss. The norm here breached is the rule requiring the public body to direct itself correctly as to its powers. It protects the public interest in having the body act lawfully. But it also ensures that, as long as no lawful ground for removing the licence exists, the company's interest in retaining it is protected. The public body owes the company a duty to behave in accordance with the norm and the company has a corresponding entitlement that the body so behave. Where the body breaches the norm causing loss to the company, the principle of corrective justice dictates that the proper remedy is monetary compensation.

Imagine, secondly, that a housing authority has a duty to provide citizens with accommodation if they are homeless and in priority need. Suppose that the authority unreasonably refuses to provide an applicant with 
accommodation and that there is a significant period before the rectification of the decision during which the applicant is homeless. The authority owes the applicant a duty to deal with her application reasonably and the applicant has a corresponding entitlement that the authority do so. Where the authority breaches the norm causing harm to the applicant in the form of homelessness, the principle of corrective justice demands that the authority repair the loss by paying compensation.

An objection sometimes made to the idea of liability based on public law unlawfulness is that the impugned decision cannot be said to cause harm to the claimant because it can be taken again lawfully with the same result. In the two examples previously given, however, the unlawfulness is of the sort that enables the court to say that the authority has reached substantively the wrong outcome. Such substantive unlawfulness is unusual outside the field of human rights law but even where there are no grounds for saying that a lawful decision-making process will produce a different outcome from the unlawful decision-making process that preceded it, breach of procedural norms may have produced harm to the persons affected. So for example, delay in the making of a decision may cause loss of economic opportunities while the refusal to allow affected persons to participate in the making of a decision and the failure to give reasons may cause anxiety and distress to the persons affected. It is arguable that these kinds of harms should also be the subject of compensation.

The numbered steps above may be presented in a different order. Doing so brings out a different facet of the argument.

1.Public authorities owe duties to the citizens affected by their actions to treat them in accordance with the norms of public law.

2.Breach of such duties calls for a remedy. At present public law provides a remedy in most circumstances in which its norms are breached: a citizen can have an unlawful act which affects her quashed, in some cases she can prevent such an act before it occurs and she may also be able to compel an authority to perform some act affecting her interests which it is obliged to perform. But where somebody suffers a loss as a result of unlawful administrative action, public law provides no remedy.

3.In accordance with the principle of corrective justice (as defined in Step 2 of the first version of the argument described above), the natural solution is that where a public authority causes harm to a citizen by breaching the duty it owes to that citizen to treat her in accordance with a norm of public law, it must repair the harm. 
Putting the argument in this way brings out a significant feature of current English public law, namely that it involves a form of unequal treatment. The victim of unlawful administrative action who applies for a remedy before the action causes loss is able to obtain one, whereas the victim of such action who, through no fault of her own, is not able to apply for a remedy before it causes loss is left with none.

The foregoing gives a rough idea of the grounds that might be advanced for developing a form of liability for harm-causing acts that are unlawful as a matter of public law. To gain a slightly fuller picture of a how a form of liability like that justified by the argument might work, a little more needs to be said about the picture of public law it assumes and the implications of this picture. I present the account, again, in the form of a series of numbered steps.

1.Every public authority exists for some purpose or set of purposes. In other words, every public authority has some overarching duty or mission. Typically, assigning such an overarching duty is a matter of statutory interpretation.

2.A public authority is obliged at all times to act in pursuit of its overarching duty or mission. It has no private purposes.

3.A public authority must also exercise its powers in accordance with the norms of public law. The norms in question are those familiar to us from judicial review. What duties a public authority is subject to in any given situation is a question to be determined by reference to the relevant statute as interpreted in the light of the norms of public law. ${ }^{9}$

4. With these propositions in mind, we can address the question of how a public authority can be said to owe duties to individuals in particular situations. Not every public authority owes duties to individuals and public authorities that do owe duties to individuals will often perform acts that do not involve them in any such duty. In general terms, a public authority will owe a duty to an individual where a reasonable authority would have that individual in contemplation as likely to suffer harm to some protected interest as a result of its actions. To be slightly more specific, there are two main types of circumstance in which such a duty might arise. Firstly, it may be part of the authority's mission to assist individuals in some way. This is obviously so, for example, in the case of many welfare functions such as those concerned with the provision of

\footnotetext{
${ }^{9}$ I leave aside here the question of public authorities, such as the Crown or the police, the source of whose powers is not statutory.
} 
housing, education or nursing care. In such cases, where, as in the homelessness example above, a person applies to the authority for a benefit, there is little difficulty in discerning a relationship between authority and applicant and any reasonable authority would have in contemplation the applicant and the likely effect of its decision on the applicant's interests. On this basis, we can say that the authority owes the applicant a duty to decide her case in accordance with the norms of public law. This does not entail that the authority is obliged to make the decision in the applicant's favour and deliver the requested benefit. But there might be a situation, as postulated in the example above, in which it was unreasonable for the authority to do otherwise and if it did do otherwise we would be able to say that the authority had breached its duty to the applicant and thereby caused loss. The authority might also breach one of the norms of procedural propriety and thereby cause harms such as anxiety or distress.

We may also say of an authority whose mission it is to deliver a certain sort of benefit to individuals that it ought to have in contemplation a particular individual even though the individual in question has not applied for it. This might be the case for example where an authority whose mission is child protection receives reliable information that a particular child is in danger of harm. As a reasonable authority, it ought to act on this information, and this puts it in a relationship with the child in question: it owes the child a duty to deal with her case in accordance with the norms of public law.

5.It goes without saying, of course, that the overarching duty of many public authorities is not to assist individuals. Some indeed, can only be plausibly regarded as serving very general public interests. This would be true, for example, of an agency that protected some feature of the environment or of the Bank of England in its role as the setter of interest rates. But often an authority can only attain its assigned ends by determining or interfering with the rights of individuals and here again it is natural to speak of there being a relationship between the authority in question and the individual affected by its actions. This is the second type of circumstance in which a duty to an individual may arise, the hypothetical case above of the licensing authority being an example. Its public mission is to serve the public interest in the availability of safe drugs. But in fulfilling this mission it must determine whether private persons have the right to market the drugs. The authority owes such persons a duty to decide their cases in accordance with the norms of public law. 
Not every harm caused by the breach of a public law duty owed to an individual by an authority is of the sort that could properly be the subject of compensation. Citizens should not expect to be compensated because they are mildly exasperated by some instance of procedural propriety. Nor should they expect to be compensated for the absence of some benefit that would have accrued to them as a result of a favourable decision of a public authority if the benefit was not one that it was part of the mission of the authority to confer. ${ }^{10}$ Three broad types of harm would be proper subjects for compensation: firstly, interests in receiving the benefits which it was the purpose of a particular public function to provide, the corresponding harm being the absence of or failure to receive the benefit; secondly, interests generally recognized in positive law as a whole such as those in person and property, the harm consisting in the infringement of these; and thirdly, the interests referred to above that might be harmed by the failure to observe procedural propriety in making decisions relating to holders of either of the first two types of interest.

As described so far, the form of liability contemplated would arise only in cases that might also be the subject of judicial review. But this would be to underestimate the reach of public law. We tend to think of public law as only concerned with cases in which public authorities make formal determinations of the kind that are usually the focus of judicial review. By the same token we tend to think of acts done in the course of practical activities carried out by public authorities through their employees - such as the fighting of a fire by the fire brigade, or the cleaning of a watercourse by an internal drainage board - as being within the purview of negligence and not of public law. This way of thinking is merely, however, a product of the current remedial structure of English law and not defensible as a matter of principle. A public authority is obliged, as a matter of public law, to act reasonably so as to ensure that its actions conduce to the public purpose that it exists to attain. This explains, why, for example, the fire brigade must act reasonably in making policy decisions as to levels of staffing, what equipment to buy and so forth. But it also entails that the fire brigade must act reasonably when actually fighting fires: just as unreasonable decisions about staffing and equipment would cause the fire brigade to fail in its duty to protect the public from the dangers of fire so too would unreasonable decisions on the ground. But whereas reasonableness in the former context would involve the traditionally recognized public law virtues of taking into account relevant considerations

\footnotetext{
${ }^{10}$ So, if for example, an authority has a duty to inspect buildings to ensure that they are safe, the owner of a building should not be able to claim compensation if she suffers loss because the authority's inspection failed to disclose a defect in the building that made it less valuable but did not render it unsafe.
} 
and ignoring irrelevant ones, reasonableness in the latter context would be a matter of practical competence. It would closely resemble what we usually think of as constituting reasonable conduct in the context of negligence law. ${ }^{1}$

A similar argument can be made even in relation to those functions that are normally thought of as purely administrative in nature. If the tax authorities decide that a citizen is entitled to a tax rebate, they are then under an obligation to send the citizen in question a letter containing a cheque and this means that the clerk charged with carrying out the task must not forget to do it or post the letter to the wrong address or include a cheque in the wrong amount. In other words, reasonableness on the part of the authorities involves the competent implementation of their higher level decisions as well as the original making of those decisions.

If it is accepted that public authorities are under a duty to perform their practical tasks with reasonable competence, then duties to particular individuals to do so will arise according to principles similar to those described above as determining when duties to individuals arise in the making of formal determinations. Such duties will arise: where an authority has already decided to confer a benefit on a given individual; where, despite not having decided to confer a benefit on a given individual, an authority is under an obligation as a matter of public law to do so; or where any reasonable authority would foresee that a failure on its part to perform one of its activities with reasonable competence would harm an important interest of an individual, one recognized in general positive law.

We can illustrate each of these different types of circumstance by reference again to the case of the fire brigade.

i)Where the fire brigade, in pursuit of its overarching duty to protect the public from fire, undertakes to put out a fire at a house belonging to a given individual, then it will be under a duty to the individual in question to act with reasonable competence in trying to put out the blaze.

ii) Where the fire brigade has not undertaken to put out a particular fire but where it is unreasonable, given its overarching duty, not to do so, it will also be under a duty both to attempt to put out the fire and to do so with reasonable competence.

iii) Where the fire brigade has undertaken to put out a fire at a house belonging to an individual and it is foreseeable that in doing so it may cause harm to recognized interests of the individual, such as person or

\footnotetext{
${ }^{11}$ For an attempted refutation of the assumption that there are two distinct species of reasonableness, one appropriate to negligence and the other to public law, in Towards a Public Law of Tort (n 8) 72-74.
} 
property, it will be under a duty to the individual to act with reasonable competence in seeking to avoid causing the harm in question. Here the duty is identical to the duty the fire brigade would be under in negligence. On the view set out here it owes such a duty concurrently in both negligence and in public law.

Once it is recognized that the reach of public law extends well beyond the range of cases traditionally dealt with in judicial review, it becomes clear that a satisfactory form of administrative liability must extend equally far, from cases generally thought of as belonging to public law such as the case of the wrongfully withheld licence to cases like that of the fire brigade. I hope it is clear from the above, however, that this does not necessarily entail that there will be liability wherever a public authority harms or fails to confer a benefit on a citizen. It must first be established either that the authority's overarching mission is to assist individual citizens in some way or that the exercise of its powers is likely to infringe in some ways citizens' recognized interests. Then it must be established that the authority owes a duty to the particular claimant either because the reasonable exercise of the authority's power would bring the claimant within its contemplation or because it has undertaken to assist the claimant. And it must also be shown that the authority's unlawful behaviour has caused one or more recognized forms of harm to the claimant. One way of implementing liability of this type, would be to identify the duty of care in negligence with the public law duties whose existence I have postulated above. If this were done, the existence of a duty of care could be denied if its imposition would tend to stultify the authority in the performance of the function to which it related.

The development of a specialised branch of the law of negligence would be one way of implementing the form of liability I propose. No doubt it might be possible to develop instead other existing torts such as misfeasance in a public office. The most likely method would of course be legislation. But it should not be supposed that the legislative enactment of a form of liability like that outlined here would result in something separate from tort law that could be safely disregarded by tort lawyers. The form of liability proposed here overlaps so much with the existing law of tort and shares so many of its concerns, that it would belong as much in the civil law courts as in the Administrative Court. 


\section{THE GORRINGE CASE AND LIABILITY FOR NONFEASANCE}

\section{Gorringe}

In Gorringe $v$ Calderdale Borough Council, ${ }^{12}$ the claimant was injured when she drove her car too fast over the crest of a dangerous hill and hit a bus coming in the other direction. At some time in the past, the word "slow" had been painted on the road as it approached the crest but this appeared to have been obliterated by subsequent resurfacing. Section 39 of the Road Traffic Act 1988 provided:

(2) Each relevant authority - (a) if it is a local authority, must prepare and carry out a programme of measures designed to promote road safety...(3) Each relevant authority - (a) must carry out studies into accidents arising out of the use of vehicles (i) if it is a local authority, on roads or parts of roads ...within their area...(b) must, in the light of those studies, take such measures as appear to the authority to be appropriate to prevent such accidents, including...the construction, improvement, maintenance or repair of roads for the maintenance of which they are responsible and other measures taken in the exercise of their powers for controlling, protecting or assisting the movement of traffic on roads.

The claimant argued that that the authority owed a common law duty of care to act reasonably in the fulfilment of its duty under s.39 to improve the safety of the roads in its area. The duty had been breached, she argued, by the authority's failure to give further warning of the dangerous nature of the crest.

The Court of Appeal accepted that in principle the authority might owe a duty to improve the road markings if it would be unreasonable in the light of its duty under s.39 not to and it conducted an inquiry into the reasonableness of the authority's system for calculating the frequency of accidents on different parts of the road system and for deciding where to spend its budget. In doing so it followed the approach laid down by Lord Woolf in an earlier case about s.39, Larner v Solihull Metropolitan Borough Council. ${ }^{13}$ May and Stuart-Smith LJ found the system reasonable while Potter LJ, dissenting, found that it was not.

By contrast, the House of Lords rejected the idea that a common law duty to act could be based on the existence of a statutory power. It held that there

${ }^{12}$ [2004] UKHL 15, [2004] 1 WLR 1057.

${ }^{13}$ [2001] RTR 32 (CA). 
was no duty of the sort that could give rise to an action for breach of statutory duty and, that in the absence of a duty deriving from statute it would be wrong to impose a common law duty in negligence. The authority's failure to improve the existing road markings was thus a case of pure nonfeasance. There were no grounds for making it liable for the claimant's injury.

Gorringe is an important case. It illustrates the way in which a case involving public authority liability can cross the boundaries between public law and the ordinary law of tort. On the one hand, the harm suffered by the claimant was physical injury of the sort that commonly forms the subject of negligence actions. On the other hand, the alleged fault of the defendant authority consisted in a failure to fulfil its statutory duties in the way required by the norms of public law and this failure could in principle have been challenged in judicial review. ${ }^{14}$ In undertaking a review of the reasonableness of the authority's actions, the Court of Appeal adopted an approach very similar to that advocated in the argument above. The House of Lords rejected this approach and by insisting that a common law duty of care cannot be based on a statutory power or duty effectively overruled a long line of earlier cases going back to Anns v Merton Borough Council. ${ }^{15}$

\section{Misfeasance and Nonfeasance}

In his article 'The Liability of Public Authorities for Failing to Confer Benefits, ${ }^{16}$ Donal Nolan examines the case and ends by endorsing the distinction between misfeasance and nonfeasance upon which the House of Lords' decision depends. In his discussion of the distinction, he begins by considering Lord Hoffmann's observations in the earlier highway case of Stovin $v$ Wise. ${ }^{17}$ According to his lordship, the two justifications usually given for the rule were that to impose on private individuals a duty to help others might be unduly burdensome and that there is often no principled reason to impose a duty to help on one particular individual rather than another (the 'why pick on me' argument). Neither applied to public authorities since, in most cases in which it was alleged that they had failed in some duty to assist

\footnotetext{
${ }^{14}$ For other examples of negligence cases involving physical harm of which the same might be said see e.g. Thomson v Home Office [2001] EWCA Civ 331 (negligence action by prisoner attacked by fellow prisoner with razor blade disputing reasonableness of prison governor's policy of allowing prisoners to use razorblades) and Miller $v$ Greater Glasgow Health NHS Board 2011 SLT 131 (negligence action by patient who contracted MRSA in hospital based on defective nature of hospital's infection control policy).

15 [1978] AC 728 (HL).

16 (2011) 127 LQR 260.

${ }^{17}$ [1996] AC 623 (HL) at 946.
} 
the claimant, they existed for the very purpose of rendering assistance of the sort in question. Nolan notes that these are not especially good justifications for the general presumption against liability for nonfeasance. They do not satisfactorily explain, for example, why an ordinary private person should not be liable for an omission to act in circumstances in which to act would not be unduly burdensome and in which there are no or few other people who could render the assistance required. ${ }^{18}$ But, Nolan argues, there are more convincing justifications for the differential treatment of misfeasance and nonfeasance. Here he cites Tony Honoré, 'who argues that in general harmful abstentions are less culpable than wrongful acts, because while the latter constitute inroads on security, the former threaten only the expectation of improvement, a different and secondary value.'

Honoré's argument is false, however, and to see why it is useful to examine the essay in which it is made. ${ }^{19}$ Honore begins the essay by pointing out, first of all, that at the level of the general background duties that each of us owes to all the world, there is a good reason to treat misfeasance as more culpable than nonfeasance. The reason is that we can all easily bear duties to refrain from acting so as to harm others but we cannot so easily bear duties to assist others. It is also easier to assign duties to help particular others to persons who have some particular reason for helping those others than it is to assign such duties to citizens in general or to anyone who might be able to help. In other words, Honore starts with the same position as that set out by Lord Hoffmann in Stovin. Honore also acknowledges that there are many situations in which a person may be said to come under distinct, as opposed to background, duties to others and that in these situations it often appears to matter little whether the duty-holder harms the person to whom the duty is owed by acting or by failing to act. So, for example, a parent will be held equally culpable for beating or for starving her child. Moreover, Honoré tells us, distinct duties may often have greater weight than background ones. Honore provides a familiar list of the types of circumstance in which distinct duties may arise: where $\mathrm{D}$ creates a danger which she is then under a duty to prevent harming others; where $\mathrm{D}$ holds some special position of responsibility; where there is a relationship of dependence between $\mathrm{D}$ and

${ }^{18}$ Nolan mentions in this connection Weinrib's article 'The Case for a Duty of Rescue' (1980) 90 Yale LJ 247 at 262 and A Beever, Rediscovering the Law of Negligence (Hart 2007) 210. He is presumably thinking of cases like those of the man who does nothing to help a child drowning in a shallow pond. In such a case, the child can be saved without an undue burden being imposed and if he is the only person present, or one of a small number, the 'why pick on me' argument has no purchase.

${ }^{19}$ T Honoré, 'Are Omissions Less Culpable?' in P Cane and J Stapleton (eds) Essays for Patrick Atiyah (Oxford, Clarendon Press 1991). 
another; where someone has conferred a benefit on D and she therefore owes a duty in return; and where $\mathrm{D}$ has made an undertaking.

Honoré's aim, I take it, is to show that there are reasons for treating misfeasance as more serious than nonfeasance that go beyond this basic distinction between background duties and distinct duties. If it were not, there would be no reason to say anything more once the basic distinction had been made. Moreover, to make good the proposition that misfeasance harms security more than nonfeasance it is not sufficient to give examples in which the situations compared both involve background duties, because in such cases the difference in seriousness between misfeasance and nonfeasance can be explained by reference to the basic distinction. This can be seen if we consider an example that Honoré seems to think supports his security argument. He says that someone who drops litter is more culpable than someone who fails to pick up the same litter even though the harm caused and the likely effort that would be required to do the right thing would be the same in each case. But here Honoré is comparing two background duties: the duty that a citizen owes to society as a whole not to drop litter and the duty that a citizen owes to society as a whole to pick up someone else's litter. The greater culpability of breach of the former duty can be explained by the second, "why pick on me" justification for the original point about background duties. We can see this more clearly if we make a comparison of the relative culpability of someone who drops litter with someone whose job it is to pick up the litter and who fails to do so. Here it is much less clear that misfeasance is worse than nonfeasance.

Note also that if, contrary to the argument of the previous paragraph, it is the point of Honore's argument merely to show that misfeasance is worse than nonfeasance at the level of background duties then the argument has no relevance to the legal problem under discussion. It is generally accepted that at the background level there should be liability for misfeasance and not for nonfeasance and no one suggests that at the background level public authorities should be liable to help citizens simply because they are practically speaking able to. No one argues, for example, that the fire brigade should be liable for failure to take injured persons to hospital or that the police should be liable for failure to put up adequate signage at a dangerous junction just because they might be capable of performing these tasks. The case made above for duties of care flowing from the statutory duties of public authorities was based on the idea that public authorities owe distinct duties to citizens who would be within their contemplation if they exercised their powers reasonably. A public authority whose mission is to protect some particular interest of citizens can quite comfortably, I suggest, occupy Honoré's category of persons who are under distinct duties because they hold a position of special responsibility. 
Turning, then, to the question of what Honoré says in support of the proposition that at the level of distinct duties misfeasance breaches security more than nonfeasance, the answer is 'very little'. If one makes a series of pairwise comparisons of instances in which similar kinds and degrees of harm are caused by wrongful acts and wrongful failures to act the idea that one is worse than another or that one breaches security more than the other is quickly undermined. So, for example, Honoré suggest that a wage cut is worse than the failure to receive a pay rise. I suggest, however, that whether this is so depends entirely on the context and what one has been led to expect. If you work in a company that has been doing badly because of the recession and the necessity of a pay cut has been discussed and the pay cut then turns out to be only $5 \%$ of your income, you may be relieved. If, by contrast, you were confidently expecting a Christmas bonus worth $10 \%$ of your income and you have already bought expensive Christmas presents on that assumption then you may be gravely disappointed with a bonus worth only $5 \%$ of your salary. In any case, the characterization of either act on the part of your employers as misfeasance rather than nonfeasance is open to question since, at bottom, the employer has a positive duty to pay wages which is derived from an undertaking he has made towards you: even a wage cut can be characterised as a kind of nonfeasance.

Let us take two more examples. Compare someone who is injured in a car crash as a result of the negligent driving of another with someone who suffers the same injury in a train crash which occurs as result of a negligent failure to properly maintain the track. Note in this instance that the train is operated and the track maintained by different companies so that it cannot be said that the person who causes harm by their nonfeasance created danger that it was their duty to avert. Take secondly the example of a haemophiliac. In one case, someone cuts her by accident and she suffers serious loss of blood. In another case, she cuts herself by accident, starts to bleed and calls an ambulance that fails to arrive due to the negligence of the ambulance crew. Can we say that the act of the person who cuts her by accident is worse than the omission of the negligent ambulance driver?

The assertion that misfeasance poses a greater threat to security than nonfeasance gains a superficial plausibility from the fact that the word 'security' tends to connote freedom from physical harm and from the thought that direct acts of violence to the person and many accidents consist in, or are primarily the result of, positive acts. But as the last two examples above show, citizens' freedom from physical harm is guaranteed in part by a system whereby many groups of persons are under positive obligations (ones whose breach would be nonfeasance) to provide some form of protection from 
physical harm. ${ }^{20}$ The fact is that we rely for our security as much on the performance of their duties by people who owe us positive duties to act as we do on people refraining from harming us. Modern society is a cooperative venture in which risky activities are undertaken and the risk is kept at an acceptable level both by requiring people to refrain from exacerbating the risk and by putting many people, including often public officials, under duties positively to act so as to avert, abate or minimise the risk. Our security rests on a pattern of expectations and if there is harm to it, it is as likely to be because of nonfeasance as misfeasance.

None of this goes to undermine the misfeasance/nonfeasance distinction altogether. But the only sound basis for the distinction is the initial consideration that it is easier to justify a background duty to refrain from harming others than it is to justify a background duty to help others. Nolan is right, of course, that this consideration does not provide a complete justification for the rule against liability for nonfeasance that we have in English law. It does not, for example, justify the rule that there can be no liability where a citizen makes no attempt to help a child drowning in a shallow pond. But this just goes to show that in English law the misfeasance/nonfeasance distinction is pushed to a point further than the arguments that justify it will support. Contra Nolan and Honore there are no other, better arguments that can justify the practice of English law in this respect and as Lord Hoffmann pointed out, the basic argument that provides

\footnotetext{
${ }^{20}$ Note in this connection, a passage from Honoré's earlier work with Hart Causation and the Law ( $2^{\text {nd }}$ ed, OUP 1985) 37: 'Though what is treated as normal represents in many ways our practical interests and our attitude to nature, it would be wrong to identify as the normal and so always as part of the "mere conditions" of events the course of nature unaffected by human intervention. This is an over-simplification, because what is taken as normal for the purpose of the distinction between cause and mere conditions is very often an artefact of human habit, custom or condition. This is so because men have discovered that nature is not only sometimes harmful if we intervene, but is also sometimes harmful unless we intervene, and have developed customary techniques, procedures, and routines to counteract such harm. These have become second "nature" and so a second "norm". The effect of drought is regularly counteracted by governmental precautions in conserving water or food; disease is neutralized by inoculation; rain by the use of umbrellas. When such man-made normal conditions are established, deviations from them will be regarded as exceptional and so rank as the cause of harm. It is obvious that in such cases, what is selected as the cause from the total set of conditions will often be an omission which coincides with what is reprehensible by established standards of behaviour...' The authors' primary concern in this passage is to show that omissions can be causes. But the passage also tends to support the view that, generally speaking, harm-causing omissions - which is to say instances of nonfeasance that take place in the context of distinct duties - are no less serious than harm-causing acts.
} 
such justification as there is has little application to the case of public authorities.

A final observation in relation to Honoré's argument concerns again its relevance. Suppose that the argument somehow succeeded in showing, in the context of distinct duties, that misfeasance was worse than nonfeasance. What significance would this have for the present debate? Nolan's use of the argument is intended to show that where a public authority fails to discharge a public law obligation to assist a citizen it is somehow to be taken less seriously than if a person (public or private) who has incurred a distinct duty on private law principles to assist another fails to discharge that duty. But a general argument of the sort that Nolan imputes to Honoré could just as well be taken to show that nonfeasance was less serious than misfeasance in the latter case as it could be taken to show that nonfeasance was less serious than misfeasance in the former case. The lesson is that only arguments that are aimed specifically at demonstrating that the interests recognized in public law are worthy of a lower level of protection than are those recognized in the orthodox law of tort will achieve the result Nolan wants.

He offers two of these but they are extremely weak. ${ }^{21}$ I quote the first:

"...as Simmonds has observed, "the more extensive the protective scope of the state's authority, the less we will be inclined to regard tragedies as the result of ill-fortune, and the more we will seek to ascribe blame", 22 and yet it seems paradoxical that the more things that governments do, and the more measures which they take to protect the public, the more likely it is that they will be criticised (and possibly sued) for not doing more. Indeed, it has been argued that this paradox is a potentially dangerous one, since attaching liability to government attempts to protect citizens may deter the state from involving itself in such matters, though obviously this danger would not arise if the withdrawal of state protection would be politically unacceptable, as it obviously would be in areas such as policing and social services." 23

21 He also offers a further consideration in favour of the basic misfeasance/nonfeasance distinction namely the support they find in the works of the rights theorists Allan Beever and Robert Stevens. I advert again to this aspect of his argument in my conclusion below.It Suffice it to say here that the other reasons he advances to support his view suggest that he does not really find Beever's and Steven's positions plausible himself.

22 Here Nolan cites NE Simmonds, 'Justice, Causation and Private Law' in M D'Entrèves and U Vogel, Public and Private: Legal, Political and Philosophical Perspectives (Routledge 2000)171.

${ }^{23}$ Ibid 285. 
To begin with the first sentence in this passage, it is of course true that the more one creates the expectation that people will be protected from particular harms, the more likely one is to be criticised if the protection in question is not forthcoming. This is hardly a reason for not providing the protections in the first place. If it were, then we ought to go back to a time when, for example, the poor were allowed to live in a state of semi-starvation or grow up illiterate or when fatal infectious diseases were allowed to spread unchecked through the population. ${ }^{24}$ But the point of the passage is that somehow attaching liability to pay damages to the failure to perform public functions, in addition to all the other remedies that may be invoked for dealing with such failure, might discourage the state from taking up such functions.

This argument has little to recommend it. Public authorities are already subject to liability in relation to many of the services they provide. The NHS can be sued for failure to provide adequate health care; ${ }^{25}$ education authorities can be sued for failure to adequately address a child's education needs; ${ }^{26}$ child protection authorities can be sued for failure to remove children suffering abuse from their families; ${ }^{27}$ highway authorities can be sued for failure to maintain the highway. ${ }^{28}$ And in cases where there is no liability for nonfeasance there is often the possibility of liability for misfeasance: so, for example, the work of the police and of the fire services carries very real risks of positively causing harm to citizens or their property and in the case, certainly, of the former, not infrequently gives rise to liability. ${ }^{29}$ The state shows no sign of withdrawing from any of these areas.

Nolan accepts that the danger of the state withdrawing from particular functions will not arise when it would be politically unacceptable to do so, and cites the cases of policing and social services. ${ }^{30}$ This admission perhaps

${ }^{24}$ It is perhaps worth adding that the fact that the provision of welfare creates expectations is one of its desirable features since the avowed aim of the welfare state is not only to remove poverty, ignorance, disease and so forth but to also to remove the fear of them.

${ }^{25}$ Bolitho $v$ City and Hackney Health Authority [1998] AC 232.

${ }^{26}$ Phelps $v$ Hillingdon LBC [2000] 3 WLR 776 (HL).

27 JD v East Berkshire Community Health NHS Trust [2004] QB 558 (HL).

${ }^{28}$ Highways Act 1980, s 41.

${ }^{29}$ See eg Taylor $v$ Chief Constable of Thames Valley Police [2004] EWCA Civ 858, [2004] 1 WLR 3155.

${ }^{30} \mathrm{He}$ also very fairly cites in a footnote Booth and Squire's argument (made in The Negligence Liability of Public Authorities (OUP 2006) 8.40) that holding public authorities liable for negligent interventions, but not for negligent failures to intervene, may have the effect of distorting their priorities in sensitive contexts such as child protection . 
undermines his argument more than he realises since it is hard to think of many areas of protection from which it would be politically acceptable to withdraw. If, moreover, the general principle were established that there should be liability where public authorities failed to act lawfully or with reasonable care in carrying out their functions, it would always be open to Parliament to override the principle in relation to a particular function if it took the view that the imposition of liability was rendering impractical the performance of the function in question.

One might also ask the question: if the imposition of liability is likely to discourage the state from providing beneficial services, why are we not worried that the imposition of liability on private persons who provide beneficial services might discourage them? The idea that someone who creates the expectation that she will provide some service or deliver some benefit will be liable if she fails to do so or falls below a certain standard in trying to do so is at the root of a number of legal doctrines, not least the doctrine that someone who assumes responsibility towards another for the performance of some task will be under a duty of care towards that other. If there is a danger of the state being discouraged from providing protections of various sorts by the prospect of liability, why is there no danger of solicitors being discouraged from drawing up wills, ${ }^{31}$ or surveyors being discouraged from surveying houses ${ }^{32}$ or employers being discouraged from giving references? ${ }^{33}$

The answer that might be given is that even where the duties in such cases arise independently of any contract between the service provider and the person to whom the duty is owed, the service provider has some incentive for providing the service: she has a contract with some other person to provide the service or stands to gain some business advantage from providing it. It might be supposed that this was a point of distinction between the case of a private professional person or service provider and the case of the state. This supposition would be mistaken., however. If we look at the matter, first of all, from a practical point of view, the legislature has an incentive to legislate for the provision of services, namely that the electorate wants and expects it. If we ascend to a higher level of abstraction, then we may think of the state as the embodiment of the citizenry as a whole and as existing to protect its members from harm and to further their welfare. ${ }^{34}$ If we think of the state in this way, then clearly it has an incentive to provide services that benefit its

\footnotetext{
${ }^{31}$ White v Jones [1995] 2 AC 207 (HL).

${ }^{32}$ Smith v Eric Bush [1990] 1 AC 831 (HL).

${ }^{33}$ Spring $v$ Guardian Assurance [1995] 2 AC 296 (HL).

${ }^{34}$ Cf Q Skinner, 'A Genealogy of the Modern State' (2009) 162 Proceedings of the British Academy 325.
} 
members and this incentive will only be removed if the cost of compensating those who suffer harm where the powers to provide the service are exercised unlawfully or carelessly outweighs the wider benefits to the citizenry as a whole. Considered at this abstract level, moreover, harm caused by the state's unlawful or careless exercise of its power is a social cost whether borne by the state itself or by the individuals upon whom it falls. Since the harm is ex hypothesi the state's fault, there is no reason why it should be borne by individuals and to leave them to bear it is unfair. ${ }^{35}$

The second further consideration that Nolan advances in support of Gorringe is that other avenues of redress may prove more efficient and effective than negligence liability. He mentions in this connection the Ombudsman, actions under the Human Rights Act and statutory or administrative compensation. Recommendations of ombudsmen do not confer on persons who have suffered harm as a result of public law unlawfulness a right to compensation, while not every instance of harm-causing public law unlawfulness involves breach of a human right, Gorringe itself being an example. Of course, it might be the case that some specialised form of statutebased public liability would do a better job of providing redress in cases like Gorringe than the law of negligence. But to assert this is to state a conclusion rather than provide an argument. To have a clear idea of what kind of solution would be better, one would have to spell out in some detail what the proposed solution would look like, something which Nolan does not do.

\section{Assumption of Responsibility}

Rejection of the idea that public authorities' possession of statutory powers and their mission to protect citizens from various ills are reasons to find that they owe a duty of care has a corollary: that in seeking to determine when authorities should be under a duty to assist others, one is bound to concentrate on the use of purely private law concepts. Nolan undertakes a careful examination of how these concepts apply in cases of nonfeasance.

$\mathrm{He}$ concludes that the doctrine of reliance affords little assistance to claimants because even where a claimant has been induced to rely on an authority by representations it has made or by the past regularity of its conduct, this is hard to prove. He then examines the doctrine of assumption of responsibility and tries to make sense of the inconsistent pattern of decisions

\footnotetext{
${ }^{35}$ I have spoken here of the state causing harm whereas Nolan is careful to talk of it failing to confer benefits. It is of course the aim of my argument to show that in relation to the kinds of situation in which a case for public authority can be made, there is no difference. But even if one uses the language of conferring benefits, it is unfair that a few people should fail to receive a benefit in circumstances in which most people receive it and in which it would normally be expected to be conferred.
} 
in relation to rescue services. He suggests that the reason why there is an assumption of responsibility and hence a duty of care when an injured person summons an ambulance but none where the fire brigade is summoned to put out a fire or the police are summoned to the scene of an emergency is that in the first case, but not in the second and third, there is a foreseeable possibility of detrimental reliance: someone who summons an ambulance is likely to renounce the alternative means of transport available to her whereas the person who summons the other emergency services is likely to have no other means of assistance to renounce. The paradoxical consequence of this reasoning is that the more absolutely dependent a citizen is on the protection provided by a public authority, the less likely the authority is to owe her a duty of care.

Nolan also rebuts the claim, accepted by judges in a number of cases, ${ }^{36}$ that where a public authority is subject to a statutory duty to act it cannot be said to have assumed responsibility towards those affected by its action because it was not acting voluntarily. Nolan argues that this view rests upon a misinterpretation of the word 'voluntary' and that in the context of assumption of responsibility an act is voluntary because it is 'conscious', 'considered' or 'deliberate'; were it otherwise, conduct done in pursuance of a contractual obligation could not amount to an assumption of responsibility.

This is true enough, but it remains the case that assumption of responsibility is an inadequate concept for deciding when a public authority should be held to owe a duty towards citizens belonging to the class of persons whose purpose it is to assist. One reason for this is that there are situations in which an authority ought to help a citizen even though, with respect to the citizen in question, it has done nothing voluntary in either the sense Nolan criticises or the one he endorses. To give an example, in the current state of the law, an authority charged with the protection of vulnerable children owes a duty of care to a vulnerable child whose need for protection comes to its attention. ${ }^{37}$ But, as Nolan points out, the decision that establishes this is inconsistent with the reasoning in Gorringe. Suppose that the position were governed by Gorringe principles and suppose further the existence of two contrasting cases. In the first, the authority is apprised of the needs of a particular vulnerable child and wrongly and carelessly concludes that the child should be left with her parents. In the second, the authority is told by a reliable informant that a particular child needs its help but does absolutely

\footnotetext{
${ }^{36}$ By Lords Bingham and Mance in Customs and Excise Commissioners $v$ Barclays Bank Plc [2006] UKHL 28; [2007] 1 AC 181 [14] and [94] respectively; by Andrew Simmons QC in Neil Martin Ltd v Revenue and Customs Commissioners [2006] EWHC 2425 (Ch) [97]; and by Dyson LJ in Rowley $v$ Secretary of State for Work and Pensions [2007] EWCA Civ 598; [2007] 1 WLR 2861 [54].

${ }^{37}$ See $J D$ v East Berkshire (n 27) above.
} 
nothing, perhaps because it is so disorganized that letters and other sources of information are simply lost or filed in the wrong place. If 'assumption of responsibility' means anything it must require the defendant to perform some act to bring itself into a relationship with the claimant. There is no such act in the second case. And yet to assert that there should be liability in the first case and not in the second, as the logic of Gorringe requires, would be to make an indefensible distinction. The underlying reason why we would regard the result in the second case as wrong is, I suggest, as follows. Where an authority exists for the very purpose of protecting children and the reasonable exercise of its power would bring it into a relationship with a particular child and where it could, by the reasonable exercise of its powers, protect the child in question then for it not to do so is wrong and culpable whether it performs some voluntary act with respect to the child or not. ${ }^{38}$

It is always open, of course, for someone who believes that the Gorringe position is correct to insist that in the cases in which there is no assumption of responsibility, the claimants have not really suffered harm, or more generally, that wherever orthodox negligence principles do not indicate the existence of a duty of care there is no harm of a sort that the law should concern itself with. The logical conclusion of this way of thinking would be to deny that there is anything wrong at all with the cases generally taken to indicate a deficiency in the law concerning administrative liability. If one took this view, one could then rejoice that our courts wisely refuse to award compensation to citizens wrongfully deprived of licenses ${ }^{39}$ or whose person or property the relevant authorities incompetently fail to protect. This does not appear to be Nolan's position, however. ${ }^{40}$

Alternatively, one can support the Gorringe position while accepting, as Nolan appears to, that there are deficiencies in our law of administrative liability. But in that case there seems little point in discussing at length how orthodox negligence principles should apply to public authorities in cases in which they are acting in pursuit of statutory duties that have no equivalent in the private sphere. A satisfactory public law solution would supplant the use of negligence and the only question that would remain for those who adopted a purely private law perspective would be where to draw the line between the system of public law administrative liability and private tort law.

\footnotetext{
38 A similar argument can be made in relation to general reliance, a doctrine that Nolan discusses sympathetically.

${ }^{39}$ As to which see the discussion of the Jain case below.

40 That it is not is indicated by his use of the quotation from Beever discussed in the conclusion below.
} 


\section{JAIN AND THE MISUSE OF LICENSING POWERS}

Nolan's approach to the problems raised by public authority liability is firstly, to endorse an approach which makes public authorities liable in tort only where a private person analogously placed would be and secondly, to assert that the special problems raised by public authorities should be cordoned off from the law of tort and treated as solely the province of public law. A distinct but related approach involves accepting that the law governing public authority liability is in certain respects unsatisfactory but insisting that its defects could be remedied by drawing upon the conceptual resources of the ordinary private law of tort.

One example of this approach is to be found in a recent article ${ }^{41}$ about the Jain case ${ }^{42}$ by Roderick Bagshaw. In Jain, the claimants were the proprietors of a nursing home. In the exercise of its statutory powers the defendant health authority made an ex parte application to the local magistrate's court for an order cancelling the home's registration. The application was made on the basis of a slipshod investigation and inaccurate information but since the claimants were not made aware of it they were not able to contest it and the order was granted. The claimants successfully appealed against the order but by the time the appeal was granted four months had passed and their business was ruined. The claimants sued the authority on the basis that it had breached a common law duty of care owed to them in making the application. Their claim succeeded at first instance but was rejected by the Court of Appeal and House of Lords. In denying the existence of a duty of care, the House of Lords held that a duty to the claimants would conflict with the authority's primary duty under the statute which was to protect the welfare of the inhabitants of nursing homes. It also held that it would be inappropriate to impose a duty of care in relation to proceedings leading to a court application, the task of ensuring that such proceedings were properly conducted being a matter for the court in question; and it emphasised that in future cases involving misuse of licensing powers a remedy was likely to be available under the Human Rights Act. ${ }^{4}$.

If one discounts the quasi-judicial nature of the process that caused the claimants' loss in Jain then it is on all fours with other cases in which the value of a business is diminished as a result of the misuse of regulatory powers. Bagshaw argues, plausibly, that it is open to doubt whether every such misuse of regulatory powers would involve breach of Convention rights.

\footnotetext{
${ }^{41}$ R Bagshaw, 'Negligently Making Business Activities Illegal: Jain v Trent Strategic Health Authority' (2009) 17 TLJ 295.

${ }^{42}$ Jain v Trent Strategic Health Authority [2009] UKHL 4 [2009] 2 WLR 248.

${ }^{43}$ The facts giving rise to the case occurred before the coming into force of the Act.
} 
He suggests that rather than thinking in terms of some general extension of administrative liability we should consider an incremental development of the law of negligence to cover the narrower class of cases to which Jain belongs. It does not seem to be Bagshaw's intention that this development should involve any fundamental rethinking of the relationship between statutory powers and duties on the one hand and the duty of care on the other,: his sole apparent motive for suggesting the development of liability in cases like Jain is that, in the words of the House of Lords, its outcome - and presumably that of other licensing cases - was 'regrettable'. And although he says nothing to suggest that a duty of care of the sort contemplated should be imposed on anyone who is not a public authority possessing regulatory powers, his idea seems to be that the incidence of the duty of care and the standard of care required should be determined on the basis of the kind of balancing of likely costs and benefits by means of which these questions are conventionally thought to be determined in the law of negligence, regardless of whether the defendant is a public authority or a private person. In other words, the standard he imagines being applied in such cases are ones that might apply to a private defendant even though there are none. ${ }^{44}$

${ }^{44}$ In an earlier article, 'Monetary Remedies in Public Law - Misdiagnosis and Misprescription' (2006) 26 LS 4, Bagshaw suggested that five problems needed to be investigated with a view to incremental development of the law: 'First, when particular classes of public professionals should be subject to professional duties, and who those duties should be owed to. Secondly, when a body charged with granting licences to others which are required to allow them to participate in a profitable activity should be required to compensate those who it has incorrectly denied a licence. Thirdly, when a body charged with regulating so as to reduce an external risk should be required to compensate those who have suffered due to a regulatory failure. Fourthly, when a body charged with investigating and prosecuting wrongdoing should be required to compensate those who have suffered harm as a result of the investigative and prosecution process. Fifthly, how a body charged with choosing between strategies which create risks for others should be required to assess those risks and evaluate them in the decision-making process, and when such a body should be held liable to pay damages for harms caused by its chosen distribution.' Liability in relation to all these areas might seem to cover so many of the cases that would be covered by a system of liability for public law wrongs that one might take Bagshaw to be in favour of such a system. But the paper from which it is drawn is a critique of the Law Commission's 2004 consultation paper on public authority liability (Monetary Remedies in Public Law) in which Bagshaw castigates the Commission for supposing that there is some general deficiency in the system of remedies available in public law or in the relationship between public authorities and tort law. His selection of problems for further investigation reflects the belief that rather than one big problem there are a number of smaller problems each susceptible of treatment in accordance with the accepted techniques of English tort law. The view expressed in the paper 
It is worth pointing out straight away that in one respect, the development Bagshaw suggests would inevitably extend to a wider class of cases than he makes explicit. Bagshaw writes of the economic loss that occurs where an activity becomes or remains unlawful as involving the wrongful denial or revocation of a license or permission. Where a license is required to perform some activity, the lack of a licence may be simply due to the licensing authority's failure to respond to an application for the licence's grant or renewal: to adapt a hypothetical illustration given by Lord Hoffmann in Stovin $v$ Wise, ${ }^{45}$ the application may simply be languishing at the bottom of a filing cabinet. ${ }^{46}$ In other words, the putative claimant may be the victim of nonfeasance rather than misfeasance and it is hard to think of a reason why this should not be the subject of liability if the positive wrongful denial of a licence can be.

But recognition of this point should lead us to ask a much larger question: if there can be liability in respect of the wrongful refusal or cancellation of a licence why should liability not be extended so as to cover a much wider range of cases in which public authorities have the power to make determinations vital to the welfare of citizens and in which the absence of liability strikes us as unfair or 'regrettable'? If (considerations of quasijudicial process aside) a health authority should be liable where it destroys a business by wrongfully cancelling a care home's registration should it not also be liable where it fails in its primary purpose of protecting the welfare of care home residents by wrongfully omitting to deregister a badly run care home? And if an authority should be liable for wrongful failure to fulfil its primary purpose of protecting some class of citizens, why should it not be liable in those cases in which its role is not a regulatory one but in which its primary purpose is to provide some benefit directly to citizens, as where it has a responsibility for housing homeless persons ${ }^{47}$ or making decisions as to

discussed in the text thus seems consistent with the views expressed in the earlier paper.

45 (n 17) 956.

${ }^{46}$ Or the authority may send the license to the wrong address so that the applicant is effectively unaware that a decision has been made in her favour. Such a failure is, I suggest, better characterized as an omission than as an act: it is a failure to do the things necessary to communicate the authority's decision to the applicant. Cf Neil Martin Ltd v Revenue and Customs Commissioners [2007] EWCA Civ 1041, [2007] All ER (D) 393.

${ }^{47}$ O’ Rourke v Camden Borough Council [1997] 3 WLR 86 (HL). 
whether to fund treatment for some unusual medical condition ${ }^{48}$ or obtaining maintenance for a mother who has separated from an abusive husband? ${ }^{49}$

Bagshaw's answer is that the regulation of economic activity affects the 'liberty' of those regulated. Presumably, then, the ground of distinction between the case of economic regulation and the case in which a public authority determines whether a citizen should receive accommodation or health care or financial assistance is that in the case of economic regulation something has been removed from the regulated person that she would normally have a right to whereas, in the other cases, the citizens concerned are appealing to the state's largesse. In other words, Bagshaw's argument appeals to the traditional notion that our liberty is the residue remaining where positive law has not intervened and represents the wrongful deprivation of a licence as constituting an incursion into that liberty by administrative action from which we require protection.

It has to be admitted that this kind of argument has a strong grip on the common law imagination. It explains why the licensing example is so often used to illustrate the inadequacy of our law of administrative liability and also why the Law Commission, in the report referred to in the introduction to this article, focused on examples of the same type when arguing for its proposed reforms. Nonetheless, it is ill founded. Once a statutory regime is introduced which determines when and whether persons can carry out a particular activity, then if there ever was a liberty to perform it (which is not always the case) the liberty is extinguished. One thinks in this connection of the effect of the Town and Country Planning Act 1947. Prior to the Act, a landowner was free, subject to the law of nuisance, to build what he pleased on his land or to change its use as he wished. The Act extinguished these rights. The ability to develop land became dependent on the grant of planning permission or the making of secondary legislation under the Act by the Secretary of State. Wherever a regulatory regime of this type is introduced, the right to act in the relevant respect becomes similarly dependent on the exercise of official discretion.

There is thus no ground in positive law for treating an authority's abuse of its power to give or withhold a licence required to perform some activity as more serious than abuse of its power to give or refuse to give some benefit directly to a citizen. In each case, some important interest of the citizen depends upon the decision of the authority and in each case, the authority must exercise the power fairly and reasonably and with due regard for the interests of the citizen concerned. At one point in his argument, Bagshaw says

\footnotetext{
${ }^{48} R v$ North Derbyshire Health Authority ex $p$ Fisher (1998) 38 BMLR 76 (QB).

${ }^{49}$ Rowley and others $v$ Secretary of State for the Department of Work and Pensions [2007] EWCA Civ 598, [2007] All ER (D) 186.
} 
in respect of marketable licences 'that a new form of intangible property may exist within the regulatory state which is sufficiently important to human flourishing to be protected alongside "property". 50 This is a much better description of the interest in issue in business licensing cases generally than the description of it as a liberty interfered with by the state, but it means that the interest in question belongs to the same category as the various benefits that public authorities have the power to bestow directly. ${ }^{51}$ For a judge to differentiate between such interests on the ground that one is a liberty and the others not would be, wittingly or otherwise, to impose an ideological preference and to create an ordering that has no sanction in existing positive law.

Underlying Bagshaw's proposal is the view that the careful piecemeal development of the law is to be preferred to grand solutions. If one remains always at the level of detail, however, one is likely to miss a larger question: should we employ a method that involves deriving duties whose breach sounds in damages from the overarching statutory duties of public authorities and from the public law norms that govern the exercise of their powers; or should we accept the blanket exclusions of this method contained in the judgments in Gorringe and Jain? To proceed in the way Bagshaw recommends is to choose the latter option by default. Yet to choose the former option would not entail the unrestricted expansion of liability to cover every case in which a public authority caused harm by its unlawful acts or omissions. If, for example, one were to try to implement the form of liability I outlined above by identifying public law duties with the duty of care in negligence it would still be possible to exclude the duty of care if its imposition was shown to be likely to stultify the authority in the performance of the function whose exercise was in issue. The starting point would be, however, that in a wide range of cases the activities of public authorities are governed by norms that exist to further and protect the interests of individual citizens and that breach of these norms can, in principle, give rise to liability to pay compensation.

\section{CONCLUSION}

Nolan concludes his evaluation of Gorringe by citing approvingly a quotation from Allan Beever's Rediscovering the Law of Negligence. ${ }^{52}$

\footnotetext{
50 (n 41) 303.

${ }^{51}$ Cf C Reich, 'The New Property' 73 Yale LJ 733 (1964).

52 (Hart Publishing 2007) 340.
} 
"The problem as identified concerns the state's obligations to its citizens. Accordingly, the appropriate place to deal with this problem, if it can be dealt with in law at all, is in the area of law that controls the relationship between the state and its citizens: public law. It may be that, for instance, the state possesses special obligations to rescue its citizens from harm that private persons do not possess. If these obligations exist, their justification lies in the nature of the state, not in the structure of tort law. Moreover, if these obligations exist, it is not necessarily the case that tort law ought to protect them. Perhaps it would be better to institute or strengthen a separate public law area of accountability ... The point is ... that, if the state has special obligations, those are a product of the kind (or kinds) of legal entity it is and not of the law of negligence ... . Tort law should not be used as the law's Swiss Army knife to fix potential inadequacies in public law. It has a structure of its own."

In its original context, this passage is, of course, the expression of a general theory. According to the theory the law of negligence exists to protect a set of primary rights and these are identifiable without reference to policy considerations and independently of the process of defining the duty of care in particular cases. A duty of care can only arise in relation to activities that create a foreseeable risk that a primary right will be infringed or where a new right arises as a result of an undertaking by the defendant. A corollary of this is that public authorities can only owe a duty of care in circumstances in which a private person analogously placed would do. There can thus be no liability in negligence for public law wrongs. In seeking to justify the decision in Gorringe, Nolan invokes this theory and the very similar one proposed in relation to the law of tort as a whole by Robert Stevens. ${ }^{53}$

The two theories are either correct or they are not ${ }^{54}$. If they are correct then they provide a complete account of what the law governing the tort liability of public authorities should be. If not, they can be ignored. It makes little sense to invoke them (as Nolan does) as one of a number of considerations that support the status quo, especially when the other

\footnotetext{
${ }^{53}$ See R Stevens, Torts and Rights (OUP 2007).

54 Most commentators have found them to be implausible: see eg C Witting, 'The House that Dr Beever Built: Corrective Justice, Principle and the Law of Negligence' (2008) 71 MLR 621; M Lunney, 'Counterfactuals and Corrective Justice: Legal History and Allan Beever's Reconstructing the Law of Negligence' (2009) 17 TLJ 219; J. Murphy, 'Rights, Reductionism and Tort Law' (2008) 28 OJLS 393; P Cane review of Stevens Torts and Rights (2008) 71 MLR 641; P Cane, 'Rights in Private Law' in Nolan and Robertson (eds) Rights and Private Law (Hart 2012).
} 
considerations include policy arguments of the sort that the theories are specifically designed to exclude.

Putting this to one side, however, the quotation is also the expression of a widely held attitude and for this reason it is worth criticising independently of any detailed consideration of the theory that supports it. Three observations are worth making. Firstly, the quotation ascribes to tort law a conceptual unity that it simply does not possess. Secondly, it assumes a clear division between tort and public law that has never existed in English law. The law of tort has always been used to hold public bodies to account. ${ }^{55}$ It remains the case that the only way of seeking a monetary remedy in judicial review proceedings is by appending a claim in tort ${ }^{56}$ and despite judicial dicta discouraging the use of public law concepts in negligence cases, ${ }^{57}$ the phenomenon whereby the public law lawfulness of an official's acts are examined in a tort action is entirely familiar. ${ }^{58}$ Given the weakness of the public/private divide in our tradition, it is quite natural to seek to address the deficiencies in our system of administrative liability by developing the law of tort. Thirdly, however, it is certainly possible to argue that it would be better to develop a discrete and purely public law monetary remedy. To do this, one would have to develop a set of functional equivalents for many of the concepts used in tort - proximity, recognized forms of harm, causation and so forth. But one can only make this argument on the basis of a proper examination of the state of public law as well as that of tort. To do it one would have to work out the dimensions of the proposed form of liability, which kinds of case it would and would not cover and how far it would encroach upon the territory traditionally thought to belong to tort. One cannot do this by adopting a purely private law perspective. Nor, in advocating such a solution, should one be motivated solely by the desire to see the orthodox law of tort continue unchanged.

To conclude, the writings I have examined in this article disclose no general a priori reason why the public law obligations of public authorities should not be reflected in duties of care or other forms of tortious duty. Nor do they make a convincing case that a satisfactory law of public authority liability can be created purely by the use of private law concepts. It may be that the best solution to the problems of public authority liability is to create a completely separate and parallel monetary remedy in public law. But this is a

55 See Dicey Law of the Constitution $10^{\text {th }}$ ed by ECS Wade (Macmillan 1959) 193. See also A Bradley, 'Administrative Law and the Law of Torts - and Unresolved Boundary Dispute?' [1989] The Law Teacher 109, 111.

${ }^{56}$ Senior Courts Act 1981 s 31(4).

57 See e.g. the speeches of Lords Slynn and Hutton in Barrett $v$ Enfield LBC [1999] 3 WLR 79 (HL) and Lord Steyn in Gorringe (n 12).

${ }^{58}$ As for example in police cases such as Mohammed-Holgate v Duke [1984] AC 437 (HL). 
solution that can only be reached by means of a full examination of both sides of the public/private divide. 